\title{
Internet Technologies in Distance Education
}

\author{
https://doi.org/10.3991/ijet.v16i10.19129 \\ Alexander Ushanov $\left({ }^{凶}\right)$ \\ Financial University under the Government of the Russian Federation, \\ Moscow, Russia \\ Ushanov 0656@mail.ru \\ Natalia Morgunova \\ Pacific National University, Khabarovsk, Russia \\ Far Eastern State Transport University, Khabarovsk, Russia \\ Irina Petunina \\ Kuban State Agrarian University named after I.T. Trubilin, \\ Krasnodar, Russia
}

\begin{abstract}
In modern education, a new format of distance learning is developing more and more rapidly - massive open online courses (MOOCs), this is especially important in times of quarantines and remote learning. The aim of the research is to study the attitude of teachers and students to MOOCs and their readiness to implement this practice in the educational process. 2145 students and 1050 teachers of higher educational institutions of the Russian Federation voluntarily took part in the study. The analysis of the survey data was made in the STATISTICA system. It has been found that more than $30 \%$ of respondents have an idea of MOOCs. It has also been determined that $31 \%$ of students and $28 \%$ of teachers are positive about the introduction of MOOCs in the educational process of universities. In addition, it has been determined that $31 \%$ of students and $23 \%$ of teachers plan to take MOOCs. Overall, the survey results showed a fairly good acceptance of MOOCs by respondents. From this, it can be concluded that in the near future, taking into account the reorganization of the educational process, MOOCs may become a worthy alternative to traditional education. It is for this that the results of this study can be used by the administration of the universities that have taken part in the survey, in order to further inform students and teachers about MOOCs. There is also a need to reorganize, revise, implement and provide an opportunity for students to study through such a form of distance learning as MOOCs.
\end{abstract}

Keywords - Distance learning, Internet technologies, massive open online courses (MOOCs), e-learning.

\section{Introduction}

Distance learning provides the opportunity to create conditions for mass continuous learning, free access to information regardless of time and place, all one needs to 
have is free access to the Internet [1]. Distance learning is closely related to Internet technologies, their synergy creates additional opportunities for changing the content, methods and principles of teaching. This system expands the opportunities for obtaining quality education at all levels, and also opens up new directions for a large number of people, regardless of social status, nationality and physical capabilities [2]. The advantages of distance learning (DL) are often called flexibility, quality, high information content, and also cost-effectiveness. The disadvantages are the lack of direct contact between the teacher and the students: difficulty in assessing the quality of the knowledge gained, determining individual characteristics, motivation to achieve the desired result [3]. In connection with the active development of applications, software, popularization of the Internet, social networks, it became logical to use Internet technologies to create a DL technical base [4]. It is already impossible to imagine education in an innovative world without MOOCs, which pose new challenges, prospects and risks for DL modernization [5,6]. Besides, significant and important is elearning via the Internet - e-learning, which is actively used on mobile phones, computers and other specialized devices [7]. This training system is well known in the West. A number of foreign experts claim that by 2020 the required minimum level of education for humanity will be higher. Due to this, the number of DL students will grow more than the number of full-time and part-time departments [8]. The main goal of the development of the DL system in the world is to enable every person, living anywhere in the world, to complete a course of study at any college or university, without reference to the place of residence. The exchange of knowledge through educational resources through the use of innovative platforms will become important [9]. DL technologies require further development, quality control of educational programs, as well as more investments from universities and government.

\subsection{Literature review}

Among DL technologies, the most promising and widely used is the Internet technology. After analysing the available Internet sources, databases, it has been found that the main forms of education in Russian Internet learning include web resources, virtual reality (especially used in medical universities), various video services, elearning, MOOCs $[10,11]$. The concepts of e-learning and DL are often used interchangeably. There are definitely points of intersection, but these are different concepts, since DL can exist in off-line and online modes, and the organization of elearning requires the Internet and electronic resources [12-16]. In addition, e-learning has initially emerged as a support system for DL, but has now grown into one of the most actively developing areas [17]. The research of e-learning market for the period 2015-2020 has shown that Asia ranks second in the implementation of distance learning, the first place is occupied by North America. Global reports over the past 5 years showed that $1.75 \%$ was income from e-learning, for example, in 2019 it was expected to reach $\$ 12.5$ billion, which could be $8 \%$ more than in $2018[18,19]$. Russian DL has a number of differences from the American and European systems. The Government of the Russian Federation has approved the state program "Development of Education" (No. 1642 as of December 26, 2017), which implies an increase in the number 
of students in educational institutions who have completed DL; in 2020 - 6010 thousand people. By 2025, more than 11 million Russians will be trained distantly [20,21]. Modern DL is impossible without the use of Internet technologies; DL is based on the following: web services, web pages, various sites, e-courses, software, forums, electronic libraries, virtual classrooms, MOODLE platforms, etc. [22,23]. DL in universities, as a rule, is implemented within the framework of the long-known part-time form of higher education. A significant difference between DL and traditional teaching technologies is that the former implies independent study of a discipline, which is organized with the help of electronic teaching materials, remote consulting, testing and control [24]. The world of Internet technologies is developing rapidly, therefore, the DL system needs to quickly respond to the conditions of the educational market and thus transform. The emergence of MOOCs in education significantly changes the view of traditional distance learning. The main MOOC's difference is the possibility of interactive communication between participants in the educational process and taking exams online $[25,26]$. The world learned about MOOC for the first time in 2008 thanks to the research of the Canadian scientist George Siemens, who was engaged in cognitive education. The course proposed by the researcher is based on the availability in time and distance of educational materials, including lectures and seminars. These courses remove the need for full-time education and university entry. Teachers, in turn, must provide all the necessary resources (material, literature, etc.) as well as use them in their own professional interests [27,28]. The first generation of MOOCs was non-linear, student-driven and chaotic. Students had to learn everything on their own. However, the second category of MOOCs implies online versions of traditional learning formats that use a knowledge transfer model using video lectures in classrooms or custom-made mini-lectures [29,30]. To work with MOOCs, one needs to place the course on one of the existing platforms that provide technical support and free access to all the necessary educational materials, and also thanks to them, the relationship between students and teachers is realized, and the assessment of the work performed. The most popular platforms are Coursera, edX and Udacity $[11,31]$. It should be understood that MOOC implies a broader concept than online education, as it opens up opportunities for free education in any university that has this technology [32]. In addition, distance learning has a successful long-term practice of using the e-learning platform MOODLE (Modular Object-Oriented Dynamic Learning Environment), the main goal of which is to implement distance learning. Distance learning courses, which are developed on the MOODLE platform, consist of two types of electronic resources:

- Those intended for the organization of the educational process, include educational materials that are used in full-time training: Lectures with presentations and text in electronic form; practical training materials and relevant presentations, notes, comments, consultations;

- Checking the work of students, completing assignments, mastering the material, checking the level of knowledge and understanding of the material. Forms of control: Tests, written assignments, reports, presentations on the work performed $[33,34]$. 
Like any other technology, distance learning has a number of learning challenges as a new form of learning. This is primarily due to the legislative framework. Traditional forms of education are based on the legally enshrined volume of academic theoretical load, while distance learning has a number of shortcomings [35].

\subsection{Problem statement}

Throughout the world, higher education systems offer students a variety of forms of learning and teaching in accordance with the Internet distance learning method. One of these forms is MOOC, which is now actively developing. A literature review has shown that the attitude of participants in the educational process to MOOCs has not been sufficiently studied. Based on this question, this study aims to identify the current status of MOOCs in the Russian education system. The aim of the research is to determine the awareness and interest of teachers and students in MOOCs.

According to the goal, the following tasks were set:

1. Determining the awareness of research participants about MOOCs.

2. Determining the attitude towards MOOC as a form of distance learning among teachers and students.

3. Comparing attitudes towards MOOCs among teachers and students.

\section{$2 \quad$ Methodology}

An empirical study was developed, organized and carried out on the basis of a given goal. 2145 students and 1050 teachers of higher educational institutions of the Russian Federation voluntarily took part in the study. The survey was conducted among 5-year students aged 20 to 23 years. The criterion for this selection is explained by the fact that senior students have the greatest theoretical and practical experience for all years of study. The response rate to the questionnaires was $63 \%$. An online survey was conducted (see Table 1). To compare the demand for MOOCs among teachers and students, the survey questions were the same for all participants. The survey became possible thanks to the deans of the faculties of the participating universities, as well as the curators of the groups.

Table 1. Questions of the questionnaire for teachers and students

\begin{tabular}{|l|l|l|}
\hline \multicolumn{1}{|c|}{ Question } & \multicolumn{1}{|c|}{ Answer (pick one answer) } & \multicolumn{1}{c|}{ Purpose } \\
\hline $\begin{array}{l}\text { Do you know about Massive } \\
\text { open online courses (MOOCs)? }\end{array}$ & $\begin{array}{l}\text { 1. Yes } \\
\text { 2. No, but I want to know } \\
\text { 3. No, and not interested }\end{array}$ & $\begin{array}{l}\text { Determine awareness and } \\
\text { interest about MOOCs }\end{array}$ \\
\hline $\begin{array}{l}\text { How do you feel about intro- } \\
\text { ducing MOOCs at your univer- } \\
\text { sity? }\end{array}$ & $\begin{array}{l}\text { 1. Positively } \\
\text { 2. Negatively } \\
\text { 3. I find it difficult to answer }\end{array}$ & $\begin{array}{l}\text { Determine the attitude towards } \\
\text { the introduction of MOOCs in } \\
\text { the university }\end{array}$ \\
\hline $\begin{array}{l}\text { Do you have any experience of } \\
\text { participating in MOOCs? }\end{array}$ & $\begin{array}{l}\text { 1. Yes } \\
\text { 2. I plan to undergo training } \\
\text { 3. No, and I do not plan to }\end{array}$ & $\begin{array}{l}\text { Determine the demand for } \\
\text { MOOCs }\end{array}$ \\
\hline
\end{tabular}


The analysis of the research data was carried out in the STATISTICA system. For convenience, some of the data have been transformed into tables. The margin of error is $5 \%$, about $3 \%$ of the questionnaires have been filled in incorrectly (for example, some respondents have not answered all the questions of the questionnaire).

\section{Results}

Table 2 presents the results of the awareness of students and teachers about MOOCs.

Table 2. Awareness of teachers and students about MOOCs

\begin{tabular}{|l|c|c|}
\hline \multicolumn{1}{|c|}{ Answer } & Students N= 2145 \% & Teachers N= 1050 \% \\
\hline Yes & 34 & 41 \\
\hline No, but I want to know & 42 & 48 \\
\hline No & 24 & 11 \\
\hline
\end{tabular}

According to the responses, it can be seen that there are $41 \%$ of teachers who know about MOOCs and 7\% fewer students who are aware of MOOCs. There are $6 \%$ more teachers who have answered "No, but I want to know" than students. It should be noted that among students there have been $13 \%$ more "no" answers to the question of whether they know about MOOCs than among teachers. These indicators show that more and more active participants in the educational process are interested in MOOCs, and those who do not know are taking the initiative to find out. The difference in answers between teachers and students suggests that the latter are not sufficiently informed, which needs to be corrected, since university graduates must keep up with progress in order to be competitive in the labour market.

Analysis of the answers to the questions has shown that almost one third of the respondents are interested in introducing MOOCs in universities (see Table 3).

Table 3. Attitude of teachers and students to the introduction of MOOCs in universities

\begin{tabular}{|l|c|c|}
\hline \multicolumn{1}{|c|}{ Answer } & Students, N= 2145 \% & Teachers N= 1050 \\
\hline Positively & 31 & 28 \\
\hline Negatively & 12 & 31 \\
\hline Difficult to answer & 57 & 41 \\
\hline
\end{tabular}

The rate of a positive answer is higher among students than teachers by $3 \%$. Among teachers, $31 \%$ of those surveyed have answered that they are negative about the implementation of MOOC and $41 \%$ are at a loss to answer. As for students, only $12 \%$ have answered negatively, which is $19 \%$ lower than among the teachers. $57 \%$ of surveyed students have found it difficult to answer. Based on a comparison of the answers to the question about maintaining MOOCs in universities, it becomes obvious that students are more positive about it than teachers. It can be assumed that the perception of the prospects for using MOOCs by teachers is due to the fact that they consider their educational programs as sufficient and reliable for high-quality teach- 
ing. In addition to another possible factor of negative attitudes towards MOOCs, is the lack of quality control and direct contact with teachers. At the same time, new opportunities open up for students, without special resource costs.

Next, the results of the answers of those who have studied, who are planning, and who are not interested will be considered (see Table 4).

Table 4. Experience of participation and interest in MOOC

\begin{tabular}{|l|c|c|}
\hline \multicolumn{1}{|c|}{ Answer } & Students N= 2145 \% & Teachers N= 1050 \\
\hline Yes & 6 & 18 \\
\hline I plan & 31 & 23 \\
\hline No & 63 & 59 \\
\hline
\end{tabular}

One third of the students plan to study in open courses. Most of the surveyed students, namely $63 \%$, do not plan to study on these courses. Among all respondents, $6 \%$ of students and $18 \%$ of teachers had experience of participation. As can be seen from the results in Table 3, the rate of answers to the question about planning further education among teachers is lower than among students by $9 \%$. These results indicate that, although not the majority, but a significant part of the respondents are still interested in improving their professional skills and development with the help of MOOCs. A possible positive factor is a need for retraining. It can be argued unequivocally that the positive attitude of the respondents towards MOOC is an indicator of innovative thinking.

\section{Discussion}

Modern DL has a close relationship with online environment, which poses new challenges for universities. Further transformation of the university towards online education depends on the correctness of the strategy chosen by the management. The study has shown that the introduction of distance learning courses requires knowledge of its features, especially for MOOC courses. The innovations require changes in face-to-face training, namely the availability of courses, the distribution of resource costs. It is very important to ensure the integration of science and education in the context of distance education, including scientific developments. Traditional approaches have been studied for a long time, and mass online schools have become known only in 2008. The organization of effective distance learning is relevant not only for the Russian system, but also for the systems of countries such as the United States, Great Britain and Canada. Despite the positive impact of MOOC training, its effectiveness directly depends on the number of students; according to statistics, there are from 6 to $13.5 \%$ of MOOCs graduates. Such a low percentage of students indicates a lack of popularization of massive online courses [36]. The present study's data correlate with other studies. As a result of a survey conducted in 2016, it was found that approximately $42 \%$ of teachers did not have information and did not have the skills to work with massive online courses, about $26 \%$ had superficial knowledge, because they were not interested in such courses [26]. The present research shows that 
the majority of the surveyed students are interested in MOOC. Other studies have identified 4 main types of student interest. The criterion for determining the type was the desire to study in such courses. The first type includes students who prefer faceto-face studies and have no interest in MOOCs; there are not many such students, only $4 \%$. The second type includes $26 \%$ of the surveyed students who are less passive in using MOOC, most often this happens when there is no available information on the subject. The third group includes more active students, they study online in addition to full-time classes or are interested in the subject of the course. The 4th type includes students who actively use MOOC in the learning process to gain additional knowledge [37]. The study of students' MOOC preferences showed that the majority of the participants (72\%) chose MOOC because it seemed an interesting and good way to gain new knowledge. Only $14 \%$ chose MOOC because it allowed them to acquire new skills that were relevant to their daily life, and $14 \%$ were interested in expanding the knowledge provided in similar courses at their college [38].

Overall, the students had a good MOOC experience. Over 96\% indicated they would recommend MOOCs to their friends. Studies on the challenges of organizing distance learning indicate that teachers need solid leadership. Managing learners at a distance requires certain leadership characteristics such as vision, managing differences, and providing useful solutions in a timely manner [39]. In addition, teachers are under heavy pressure. They need to prepare specific courses in accordance with the needs of their students, manage their participation [40]. MOOC researchers have realized that most MOOC students leave shortly after registration. Of those who enrol in a course, $52 \%$ never use it and the reduction usually remains high in the first 2 weeks of the course. Similar patterns are seen for several years. The number of new students increased from 2012 to 2016, by $12 \%$ [41]. Scientists also note that one of the main problems of MOOC is the dropout rate, with several sources indicating that on average about $5-15 \%$ of participants complete these courses. In addition, several authors have investigated problematic aspects in course design and management, such as, for example, MOOC pedagogical model and quality. By the way, the latest MOOC developments seem to be driven by commercial interests rather than pedagogical concerns [42]. It is believed that MOOCs can seriously compete with higher education institutions. Modern companies offer their partner universities to conduct massive online training, issue certificates, etc. [43]. Analysing the experience of using distance learning, it should be noted that the most popular form is blended distance learning when several technologies are involved in the process. A literature review on the development of distance higher education, including MOOCs, in China found that by the end of 2018, approximately 201 million Chinese people, $24.3 \%$ of those who used the Internet, had received online education, an increase from the end of 2017 amounted to $29.7 \%$. Of those who completed online education, $96.5 \%$ used their mobile phones, an increase of $19.9 \%$ over the end of 2017 [44,45]. The value of the present research is that the analysis of students' knowledge about MOOC has shown that the Russian DL market requires further modernization and an expanded campaign to inform potential students. 


\section{Conclusion}

In general, the results of the survey showed favourable trends in the attitude of students and teachers towards MOOC as one of the actively developing form of distance education. From this, it can be concluded that in the near future, this form of education may become a worthy alternative to traditional education. The study has found that more than $30 \%$ of the surveyed respondents are aware of MOOCs. However, there are more MOOC supporters among students. This can be explained by the fact that the overwhelming majority of students want to find a successful job in the near future. The analysis of the results also showed that the experience of participation was higher among teachers by $18 \%$. The reason for this indicator can be explained by the desire for professional development and the discovery of new opportunities. The introduction of MOOC into the educational process in Russia is progressing at an accelerating pace. At this stage, the use of online learning technologies is not widespread and is typical for people with innovative thinking. University professors are better acquainted and have more experience with MOOCs. It is also worth noting that almost half of the respondents found it difficult to answer the question concerning the introduction of MOOCs in the educational process. For students, these courses create excellent opportunities, while for teachers - a number of difficulties, including such as competition and job loss. To compare the dynamics of MOOC development in the Russian educational space, it is necessary to repeat the study after some time. The results of this study indicate the need for more active development of MOOC in Russia in order to support and expand the distance education market. That is why these developments and already existing results can be used by the administration of the studied universities to implement the missing methodologies and provide distance learning based on MOOC.

\section{References}

[1] Anderson, T., Dron, J. (2011). Three generations of distance education pedagogy. The International Review of Research in Open and Distributed Learning, 12(3): 80-97. https:// doi.org/10.19173/irrodl.v12i3.890

[2] Shearer, R.L., Aldemir, T., Hitchcock, J., Resig, J., Driver, J., Kohler, M. (2020). What Students Want: A Vision of a Future Online Learning Experience Grounded in Distance Education Theory. American Journal of Distance Education, 34(1): 36-52. https://doi. org/10.1080/08923647.2019.1706019

[3] Simpson, M., Anderson, B. (2012). History and heritage in open, flexible and distance education. Journal of Open, Flexible, and Distance Learning, 16(2): 1-10.

[4] Pustišek, M., Kos, A. (2018). Approaches to front-end IoT application development for the Ethereum blockchain. Procedia Computer Science, 129: 410-419. https://doi.org/10.1016/ i.procs.2018.03.017

[5] Kizilcec, R.F., Pérez-Sanagustín, M., Maldonado, J.J. (2017). Self-regulated learning strategies predict learner behaviour and goal attainment in Massive Open Online Courses. Computers \& education, 104: 18-33. https://doi.org/10.1016/j.compedu.2016.10.001 
[6] Seaman, J.E., Allen, I.E., Seaman, J. (2018). Grade Increase: Tracking Distance Education in the United States. Babson Survey Research Group.

[7] Madiope, M., Govender, D. (2015). Distance education and supporting technologies for open and distance learning. In Moving beyond the hype: A contextualised view of learning with technology in higher education. Universities South Africa, Pretoria, pp. 46-49.

[8] Choudhury, S., Pattnaik, S. (2020). Emerging themes in e-learning: A review from the stakeholders' perspective. Computers \& Education, 144: 103657. https://doi.org/10.1016/j. compedu.2019.103657

[9] Zhang, X., Jiang, S., OrdóñezdePablos, P., Lytras, M.D., Sun, Y. (2017). How virtual reality affects perceived learning effectiveness: a task-technology fit perspective. Behaviour \& Information Technology, 36(5): 548-556. https://doi.org/10.1080/0144929x.2016.12686 $\underline{47}$

[10] Andreev, A.A., Soldatkin, V.I. (2013). Distance learning and distance educational technologies. Cloud of science, 1: 14-20.

[11] Bugaychuk, K.L. (2013). Massive open distance courses: history, typology, perspectives. Higher education in Russia, 3: 148-155.

[12] Gros, B., García-Peñalvo, F.J. (2016). Future trends in the design strategies and technological affordances of e-learning. Springer.

[13] Foerster, S.H. (2017). Global: Relax-Higher Education Won't Be Killed by MOOCs: University World News. In Understanding Global Higher Education. Brill Sense, pp. 151-153. https://doi.org/10.1007/978-94-6351-044-8 32

[14] Simonson, M., Zvacek, S.M., Smaldino, S. (2019). Teaching and Learning at a Distance: Foundations of Distance Education. 7th Edition. IAP.

[15] Stewart, B. (2013). Massiveness+ openness= new literacies of participation. Journal of Online Learning and Teaching, 9(2): 228-238.

[16] Tikhomirova, E. (2016). Live Learning: What is e-learning and how to make it work. Alpina Publisher.

[17] Gibson, S., Adamski, M., Blumfield, M., Dart, J., Murgia, C., Volders, E., Truby, H. (2020). Promoting evidence-based nutrition education across the world in a competitive space: Delivering a Massive Open Online Course. Nutrients, 12(2): 344. https://doi.org/ 10.3390/nu12020344

[18] Khudyakova, T.A., Beletskaya, E.S. (2016). Analysis of distance learning systems' development dynamics: foreign and Russian aspects. In Service: economics, technology, education student yearbook. SUSU Publishing Centre, Chelyabinsk, pp. 113-118.

[19] Shen, X., Wu, J., Yang, Y. (2019). Accreditation System of Distance Higher Education in the US and Its Implications for China. Journal of Contemporary Educational Research, 3(5): $24-28$

[20] The Government of the Russian Federation (2017). Decree of the Government of the Russian Federation of December 26, 2017 No. 1642 "On the approval of the state program of the Russian Federation "Development of education". GARANT - Legislation. http://www.garant.ru/products/ipo/prime/doc/71748426/. https://doi.org/10.22416/1382-43 76-2017-27-2-91-101

[21] Urintsov, A., Staroverova, O.V., Sviridova, E.S., Epifanov, G.M. (2018). State policy of the Russian Federation aimed at developing education in the digital economy. Modern information technology and IT education, 14(4): 842-850.

[22] Sciarrone, F., Temperini, M. (2020). K-Open Answer: a simulation environment to analyze the dynamics of massive open online courses in smart cities. Soft Computing, 24: 1112111134. https://doi.org/10.1007/s00500-020-04696-Z 
[23] Sun, A., Chen, X. (2016). Online education and its effective practice: A research review. Journal of Information Technology Education, 15: 157-190. https://doi.org/10.28945/3502

[24] Al-Fraihat, D., Joy, M., Sinclair, J. (2020). Evaluating E-learning systems success: An empirical study. Computers in Human Behavior, 102: 67-86. https://doi.org/10.1016/j.chb. 2019.08.004

[25] Pursel, B.K., Zhang, L., Jablokow, K.W., Choi, G.W., Velegol, D. (2016). Understanding MOOC students: motivations and behaviours indicative of MOOC completion. Journal of Computer Assisted Learning, 32(3): 202-217. https://doi.org/10.1111/jcal.12131

[26] Roshchina, Y., Roshchin, S., Rudakov, V. (2017). The demand for massive open online courses (MOOC): Evidence from Russian education. Educational Studies Moscow, 1: 131158. https://doi.org/10.17323/1814-9545-2018-1-174-199

[27] Gynther, K. (2015). Designframework for an Adaptive, Hybrid MOOC: Personalized Curriculum in Teacher Professional Development. In ECEL2015-14th European Conference on e-Learning: ECEl2015. Academic Conferences and publishing limited, p. 255,

[28] Siemens, G. (2013). Massive Open Online Courses: Innovation in Education? Open Educational Resources: Innovation, Research and Practice. UNESCO, Athabasca.

[29] Haron, H., Yusof, A.R.M., Samad, H., Ismail, N., Juanita, A., Yusof, H. (2019). The platform of MOOC (massive open online course) on open learning: issues and challenges. International Journal, 1(3): 1-9. https://doi.org/10.35631/ijmoe.13001

[30] Kocdar, S., RecepOkur, M., Bozkurt, A. (2017). An examination of Xmoocs: An embedded single case study based on Conole'S 12 dimensions. Turkish Online Journal of Distance Education, 18(4): 52-65. https://doi.org/10.17718/tojde.340381

[31] Hartnett, M. (2019). Theories of Motivation in Open and Distance Education. In Open and Distance Education Theory Revisited. Springer, Singapore, pp. 105-113. https://doi. org/10.1007/978-981-13-7740-2 12

[32] Poole, M., Davis, N., Robinson, L. (2020). Massive Open Online Courses: enhancing caregiver education and support about dementia care towards and at end of life. Age and ageing, 49(2): 171-174. https://doi.org/10.1093/ageing/afz150

[33] Beloglazov, A.A., Beloglazova, L.B. (2017). Modeling Internet-learning technologies. Bulletin of the Peoples' Friendship University of Russia. Series: Informatization of education, 14(1): 83-91. https://doi.org/10.22363/2312-8631-2017-14-1-83-91

[34] Teixeira, A.M., Bates, T., Mota, J. (2019). What future (s) for distance education universities? Towards an open network-based approach. RIED. Revista Iberoamericana de Educación a Distancia, 22(1): 107-236. https://doi.org/10.5944/ried.22.1.22288

[35] Kuleshova, E.A., Yakushev, A.Zh. (2019). E-learning in Russia: training or technology? Economy of Knowledge: Theory and Practice, 2(10): 276-283.

[36] Rice, J. (2013). MOOC versations: Commonplaces as argument. In S.D. Krause, C. Lowe (Eds.), Invasion of the MOOCS: The Promises and Perils of Massive Open Online Courses. Parlor Press Anderson, South Carolina, pp. 86-97.

[37] Androsov, K.Yu., Golubeva, G.F., Spasennikova, E.V. (2019). Prospects for the development of digital education and massive open online courses in the assessments of teachers and students. Ergo design, 4(6): 214-222. https://doi.org/10.30987/2619-1512-2019-20194-214-222

[38] Abeer, W., Miri, B. (2014). Students' preferences and views about learning in a MOOC. Procedia-Social and Behavioral Sciences, 152(152): 318-323. https://doi.org/10.1016/j. $\underline{\text { sbspro.2014.09.203 }}$

[39] Birch, D., Burnett, B. (2009). Bringing academics on board: encouraging institution-wide diffusion of e-learning environments. Australasian Journal of Educational Technology, 25(1): 117-134. https://doi.org/10.14742/ajet.1184 
[40] Hristova, A.G., Bonafini, F.C., Jablokow, K.W., Bayeck, R.Y., Park, E. (2018). How MOOC Reality Informs Distance Education, Online Learning, and Connectivism. Current Issues in Emerging eLearning, 4(1): 7.

[41] Reich, J., Ruipérez-Valiente, J.A. (2019). The MOOC pivot. Science, 363(6423): 130-131. https://doi.org/10.1126/science.aav7958

[42] Buhl, M., Andreasen, L.B. (2018). Learning potentials and educational challenges of massive open online courses (MOOCs) in lifelong learning. International Review of Education, 64(2): 151-160. https://doi.org/10.1007/s11159-018-9716-Z

[43] Zakharova, U.S., Tanasenko, K.I. (2019). MOOC in Higher Education: Advantages and Disadvantages for Educators. Education issues, 3: 176-202.

[44] Chen, W., Jia, J. (2016). Comparison of online and onsite students' learning outcomes and experiences in a massively open online course in China. Journal of Educational Technology Development and Exchange, 9(1): 67-88. https://doi.org/10.18785/jetde.0901.05

[45] Xiaobin, L.I. (2019). Distance Higher Education and MOOCs in China. Asian Journal of Distance Education, 14(1): 7-20.

\section{Authors}

Ushanov Alexander Evgenievich is a PhD of Economic Sciences, Associate Professor of the Department of Banking and Financial Markets, Financial University under the Government of the Russian Federation, Moscow, Russia. Email: Ushano v_0656@mail.ru

Morgunova Natalia Viktorovna is a $\mathrm{PhD}$ in Juridical Sciences, Associate Professor of the Department of State and Legal Disciplines, Pacific National University; Department of Customs Law and Official Activity, Far Eastern State Transport University, Khabarovsk, Russia.

Petunina Irina Aleksandrovna is Doctor of Technical Sciences, Associate Professor of the Department of Higher Mathematics, Federal State Budgetary Educational Institution of Higher Education "Kuban State Agrarian University named after I.T. Trubilin", Krasnodar, Russia.

Article submitted 2020-10-09. Resubmitted 2020-12-23. Final acceptance 2020-12-23. Final version published as submitted by the authors. 